\title{
Suppression of human breast tumors in NOD/ SCID mice by CD44 shRNA gene therapy combined with doxorubicin treatment
}

This article was published in the following Dove Press journal:

OncoTargets and Therapy

4 May 2012

Number of times this article has been viewed

\author{
Phuc Van Pham' \\ Ngoc Bich Vu' \\ Thuy Thanh Duong' \\ Tam Thanh Nguyen' \\ Nhung Hai Truong' \\ Nhan Lu Chinh Phan' \\ Tue Gia Vuong' \\ Viet Quoc Pham' \\ Hoang Minh Nguyen' \\ Kha The Nguyen' \\ Nhung Thi Nguyen' \\ Khue Gia Nguyen' \\ Lam Tan Khat' \\ Dong Van Le ${ }^{2}$ \\ Kiet Dinh Truong' \\ Ngoc Kim Phan' \\ 'Laboratory of Stem Cell Research \\ and Application, University of Science, \\ Vietnam National University, HCM \\ City, ${ }^{2}$ Military Medical University, \\ Ha Noi, Vietnam
}

Correspondence: Phuc Van Pham Laboratory of Stem Cell Research and Application, University of Science, Vietnam National University, 227 Nguyen Van Cu, District 5, HCM City, Vietnam Tel +848383977I9

Email pvphuc@hcmuns.edu.vn
Background: Breast cancer stem cells with a CD44 ${ }^{+} \mathrm{CD} 24^{-}$phenotype are the origin of breast tumors. Strong CD44 expression in this population indicates its important role in maintaining the stem cell phenotype. Previous studies show that CD44 down-regulation causes CD $44^{+} \mathrm{CD} 24$ breast cancer stem cells to differentiate into non-stem cells that are sensitive to antitumor drugs and lose many characteristics of the original cells. In this study, we determined tumor suppression in non-obese severe combined immunodeficiency mice using CD44 shRNA therapy combined with doxorubicin treatment.

Methods: Tumor-bearing non-obese severe combined immunodeficiency mice were established by injection of $\mathrm{CD} 44^{+} \mathrm{CD} 24^{-}$cells. To track $\mathrm{CD} 44^{+} \mathrm{CD} 24^{-}$cells, green fluorescence protein was stably transduced using a lentiviral vector prior to injection into mice. The amount of CD44 shRNA lentiviral vector used for transduction was based on CD44 down-regulation by in vitro CD44 shRNA transduction. Mice were treated with direct injection of CD44 shRNA lentiviral vector into tumors followed by doxorubicin administration after 48 hours. The effect was evaluated by changes in the size and weight of tumors compared with that of the control.

Results: The combination of CD44 down-regulation and doxorubicin strongly suppressed tumor growth with significant differences in tumor sizes and weights compared with that of CD44 down-regulation or doxorubicin treatment alone. In the combination of CD44 down-regulation and doxorubicin group, the tumor weight was significantly decreased by 4.38 -fold compared with that of the control group.

Conclusion: These results support a new strategy for breast cancer treatment by combining gene therapy with chemotherapy.

Keywords: breast cancer, breast cancer stem cells, CD44, doxorubicin, gene therapy

\section{Introduction}

$\mathrm{CD} 44^{+} \mathrm{CD} 24^{-}$cells have been identified as a breast cancer stem cell population and the origin of tumors, metastasis, and relapse in breast cancer patients. ${ }^{1-3}$ Breast cancer stem cell targeting is considered a promising therapy. Thus far, various drugs that are specific to receptors such as Her2/neu and epidermal growth factor receptors have been used to target breast cancer stem cells. ${ }^{4-11}$ However, more than $50 \%$ of tumors do not express these receptors and are drug resistant. ${ }^{12-16}$ A recent report has shown that triple-negative breast carcinoma contains CD $44^{+} \mathrm{CD} 24^{-}$breast cancer stem cells. ${ }^{17}$ Therefore, it is essential for treatment that new targets be discovered on breast cancer stem cells.

CD44 plays an important role in the phenotype of breast cancer stem cells and is responsible for cancer stem cell-specific characteristics, such as antitumor drug 
resistance in various cancers like colon cancer, ${ }^{18}$ salivary gland cancer, ${ }^{19}$ and metastasis from the breast to the liver. ${ }^{20}$ In addition, CD44 has been used to isolate and enrich cells that are capable of forming breast cancer tumors ${ }^{21}$ and numerous other tumors, including head and neck squamous cell carcinoma, ${ }^{22-24}$ esophageal squamous cell carcinoma, ${ }^{25}$ nasopharyngeal carcinoma, ${ }^{26}$ and gastric ${ }^{27}$ and colon cancer stem cells. ${ }^{28}$

Down-regulation of CD44 using siRNA or shRNA results in metastasis suppression, ${ }^{29}$ sensitizes cancer stem cells to drugs, ${ }^{30}$ and causes differentiation of breast cancer stem cells. ${ }^{31}$ Antibodies against survivin also show similar effects. ${ }^{32}$ CD 44 also plays an important role in other cancers. CD44 inhibition suppresses the development of colon tumors in mice $^{33}$ and inhibits the proliferation and metastasis of ovarian $^{34}$ and liver cancer cells. ${ }^{35}$ This study evaluates breast cancer treatment in mouse models using a CD44 shRNA lentiviral vector to inhibit CD44 expression in combination with doxorubicin chemotherapy.

\section{Materials and methods}

\section{Cell culture and establishment of green fluorescent protein (GFP)-expressing breast cancer stem cells}

Breast cancer stem cells were isolated and purified as described elsewhere. ${ }^{30}$ Briefly, tumor biopsies from consenting patients were obtained at hospitals and then transferred to our laboratory. Biopsy samples were washed 3-4 times with phosphate-buffered saline containing $1 \times$ antibiotic-antimycotic (Sigma, St Louis, MO), and then homogenized into small pieces (approximately 1-2 $\mathrm{mm}^{3}$ ). Homogenized samples were resuspended in M171 medium (Invitrogen, Carlsbad, CA) containing mammary epithelial growth supplement (Invitrogen) and then seeded in $35 \mathrm{~mm}$ culture dishes (Nunc, Germany). Cells were incubated at $37^{\circ} \mathrm{C}$ with $5 \% \mathrm{CO}_{2}$, and medium was replaced every third day. $\mathrm{CD} 44^{+} \mathrm{CD} 24^{-}$cells were isolated from the primary cell population by magnetic sorting using a commercial kit (Miltenyi Biotec, Germany). These $\mathrm{CD} 44^{+} \mathrm{CD} 24^{-}$cells were named BCSC1. For tracking, we established $\mathrm{CD} 44^{+} \mathrm{CD} 24^{-}$cells that stably expressed the $g f p$ gene. We used a $g f p$ lentiviral vector (Santa Cruz Biotechnology, CA) to transduce isolated CD44+CD24cells. To select and establish GFP-expressing BCSC1, cells were cultured in medium containing $10 \mu \mathrm{g} / \mathrm{mL}$ puromycin dihydrochloride (Sigma-Aldrich, St Louis, MO) for 1 week.

\section{CD44 knockdown of CD44 ${ }^{+}$CD24- cells with shRNA using lentivirus particles}

In the first assay, we determined a suitable dose of lentiviral particle vector infectious units (IFUs) to apply in the next experiment. CD44 shRNA lentivirus particles (Santa Cruz Biotechnology, Inc, Santa Cruz, CA) were stably transfected according to the manufacturer's instructions. Briefly, BCSC1 cells were seeded on day 1 in a twelve-well plate with complete medium (Dulbecco's modified Eagle's medium/F12 supplemented with $10 \%$ fetal bovine serum and $1 \times$ antibiotic-mycotic) and incubated overnight.

Medium was replaced on day 2 with fresh complete medium containing $5 \mu \mathrm{g} / \mathrm{mL}$ polybrene (Sigma-Aldrich, St Louis, MO) for 6 hours, then $20 \mu \mathrm{L}$ of modified Eagle's medium with 25 mM 4-(2-hydroxyethyl)-1-piperazineethanesulfonic acid containing $1 \times 105$ IFUs of virus was added to the culture. The culture plate was shaken to mix the virus particles and was then incubated overnight at $37^{\circ} \mathrm{C}$ with $5 \%$ $\mathrm{CO}_{2}$. On day 3, medium was replaced with fresh complete medium without polybrene. Half of the transduced cells were confirmed by CD44 detection using flow cytometry. Half of the transduced cells were selected by culturing in complete medium containing $10 \mu \mathrm{g} / \mathrm{mL}$ puromycin dihydrochloride for 12 hours, followed by $5 \mu \mathrm{g} / \mathrm{mL}$ puromycin dihydrochloride for 1 week.

\section{Flow cytometry}

Cells were washed twice in phosphate-buffered saline containing 1\% bovine serum albumin (Sigma-Aldrich, St Louis, MO). Fc receptors were blocked by incubation with immunoglobulin G (Santa Cruz Biotechnology, CA) on ice for 15 minutes. Cells were stained with anti-CD44-PE monoclonal antibodies (BD Biosciences, Franklin Lakes, NJ) at $4^{\circ} \mathrm{C}$ for 30 minutes. After washing, cells were analyzed using a FAC SCalibur flow cytometer (BD Biosciences) and CellQuest Pro software (BD Biosciences) with 10,000 events collected.

\section{CD44 shRNA gene therapy}

Female (5-6 weeks old) NOD/severe combined immunodeficiency (SCID) mice (NOD.CB17-Prkdcscid/J; Charles River Laboratories, Wilmington, MA) were subcutaneously injected with BCSC1 cells $\left(2 \times 10^{6}\right.$ cells/mouse $)$. After 2 weeks, tumors were formed and mice were divided into four groups: Group 1 (control) mice $(n=4)$ were used as untreated controls; they received biweekly intratumoral phosphate-buffered saline injections for 6 weeks. Group 2 (doxorubicin [Dox]) mice received intratumoral Dox 
injections ( $2 \mathrm{mg} / \mathrm{kg}$ ) weekly for 4 weeks. Group 3 (shRNA) mice received intratumoral CD44 shRNA lentiviral vector injections with a dose of IFUs that was doubled compared with that of the tumor cell number. Group 4 (CD44 shRNA in combination with Dox treatment [shRNA + Dox]) mice received intratumoral injections of CD44 shRNA lentiviral vector with IFUs similar to that of Group 3 and, after 48 hours, received intratumoral injections of Dox $(2 \mathrm{mg} / \mathrm{kg})$ weekly for 4 weeks. Tumor size was measured as described below. Animals were killed after 7 weeks, and tumors were excised and weighed to record the wet tumor weight. All animal experiments were approved by the Institutional Animal Care and Use Committee of Stem Cell Research and Application Laboratory, University of Science, VNU-HCM.

\section{Tumor size measurement}

Tumor size was measured with calipers in two dimensions, and size was calculated using the following formula: $a \times b^{2} / 2$, where "a" is the tumor length and " $b$ " is the diameter. ${ }^{36}$

\section{Statistical analysis}

All experimental procedures were performed in triplicate, except for mouse experiments. The significance of differences between mean values was assessed by a Student's $t$-test and analysis of variance. $P<0.05$ was considered significant.

\section{Results}

\section{Isolation and establishment of breast cancer stem cells expressing green fluorescent protein}

We primary-cultured 31 tumor samples from patients; 23 of these samples showed numerous single cells surrounding the tumor tissue. Cells from the 23 samples were allowed to propagate to $80 \%$ confluence (Figure 1A). CD44 and CD24 were analyzed and all 23 primary cell samples showed a small population of cells that were positive for CD44 and negative or weakly positive for CD24. This population constituted $3.96 \% \pm 1.72 \%$ of the total cells derived from primary culture. We isolated two populations of CD $44^{+} \mathrm{CD} 24^{-}$cells from the 23 primary-culture samples. One cell population, termed "BCSC1," was used for subsequent experiments (Figure 1B). The BCSC1 cell line was transduced with the $g f p$ gene using a lentiviral vector, resulting in $43.12 \%$ and $99.9 \%$ of BCSC1 cells expressing GFP before and after selection with puromycin, respectively (Figure 1C).

\section{Tumor-bearing mouse models}

To establish the tumor-bearing mouse models, we used 5-6week-old NOD/SCID mice. GFP-expressing BCSC1 cells $\left(2.10^{6}\right.$ cells/mouse) were injected into mammary fat using an insulin needle. This resulted in $100 \%$ of mice forming tumors that were apparent after 3 weeks. All tumors contained GFP-expressing cells (Figure 2).

\section{In vitro CD44 down-regulation by the CD44 shRNA lentiviral vector}

Next, we evaluated in vitro CD44 down-regulation with CD44 shRNA using a lentiviral vector to determine a suitable dose for in vivo transduction. CD44 down-regulation was dependent on the ratio of IFUs to BCSC1 cells, with a higher ratio of lentiviral vector to $\mathrm{BCSC} 1$ cells resulting in higher transduction efficiency. The percentages of CD44 down-regulated BCSC1 cells in the control (1:0), Dox (2:1), CD44 shRNA (1:1), and CD44 shRNA + Dox (1:2) groups were $0.14 \% \pm 0.08 \%, 12.21 \% \pm 3.30 \%, 37.87 \% \pm 5.34 \%$, and $47.41 \% \pm 3.90 \%$, respectively $(P<0.05)$ (Figure 3 ). Based on these results, the suitable dose of lentiviral vector IFUs was double that of the number of tumor cells. This dose was applied in further experimentation.
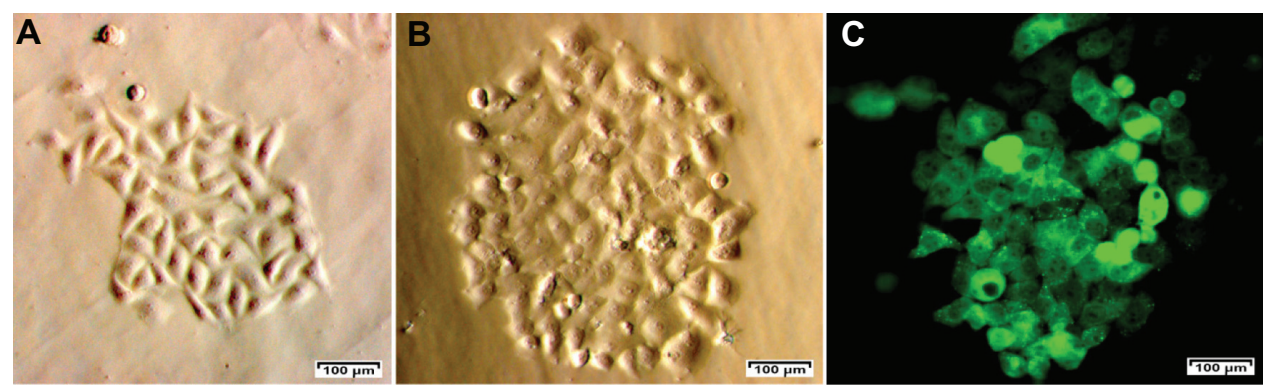

Figure I Breast cancer cells from breast tumors (A) were used to isolate CD44+CD24- breast cancer stem cell populations (B) for green fluorescent protein expression after transduction with green fluorescent protein using a lentiviral vector and selection with puromycin (C). 


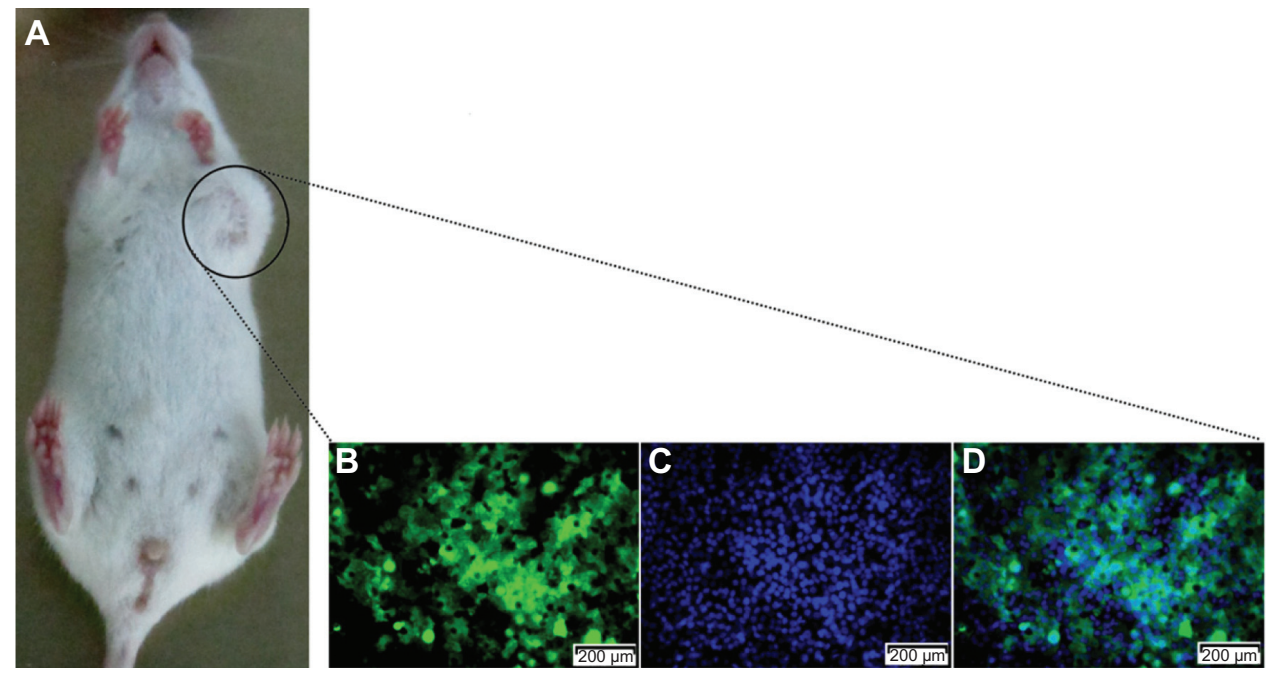

Figure 2 A tumor produced in the mouse model. The tumor (A) was excised and observed by monochromatic fluorescence microscopy (Carl Zeiss AG, Oberkochen, Germany) using fluorescein isothiocyanate (B) and Hoechst 33342 filters (Carl Zeiss AG, Oberkochen, Germany) (C) for a merged image (D).

\section{Tumor size and weight}

As shown in Figure 4, the size and weight of tumors were significantly different between the four groups $(P<0.05)$. The average tumor sizes were $246.39 \pm 56.80 \mathrm{~mm}^{3}$, $142 \pm 25.98 \mathrm{~mm}^{3}, 80.89 \pm 11.11 \mathrm{~mm}^{3}$, and $19.75 \pm 8.50 \mathrm{~mm}^{3}$ in the control, Dox, CD44 shRNA, and CD44 shRNA + Dox groups, respectively. In comparison with the control group, the tumor sizes were significantly decreased by $1.74-$, 3.04-, and 12.47-fold in the Dox, CD44 shRNA, and CD44 shRNA + Dox groups, respectively. Tumor weights also gradually decreased $(0.44 \pm 0.18 \mathrm{~g}, 0.23 \pm 0.05 \mathrm{~g}$, $0.18 \pm 0.02 \mathrm{~g}$, and $0.1 \pm 0.07 \mathrm{~g}$ ). In CD44 shRNA + Dox, the tumor weight was significantly decreased by 4.38 -fold compared with that of the control group. These changes in tumor size and weight confirmed the beneficial effects of CD44 down-regulation, Dox treatment, and particularly, the combination of CD44 down-regulation and Dox treatment. Thus, combinatorial therapy of CD44 down-regulation and Dox efficiently suppressed tumor growth in the mouse model.

\section{Discussion}

Cancer stem cells are considered the origin of malignant tissues. The existence of cancer stem cells has been recently

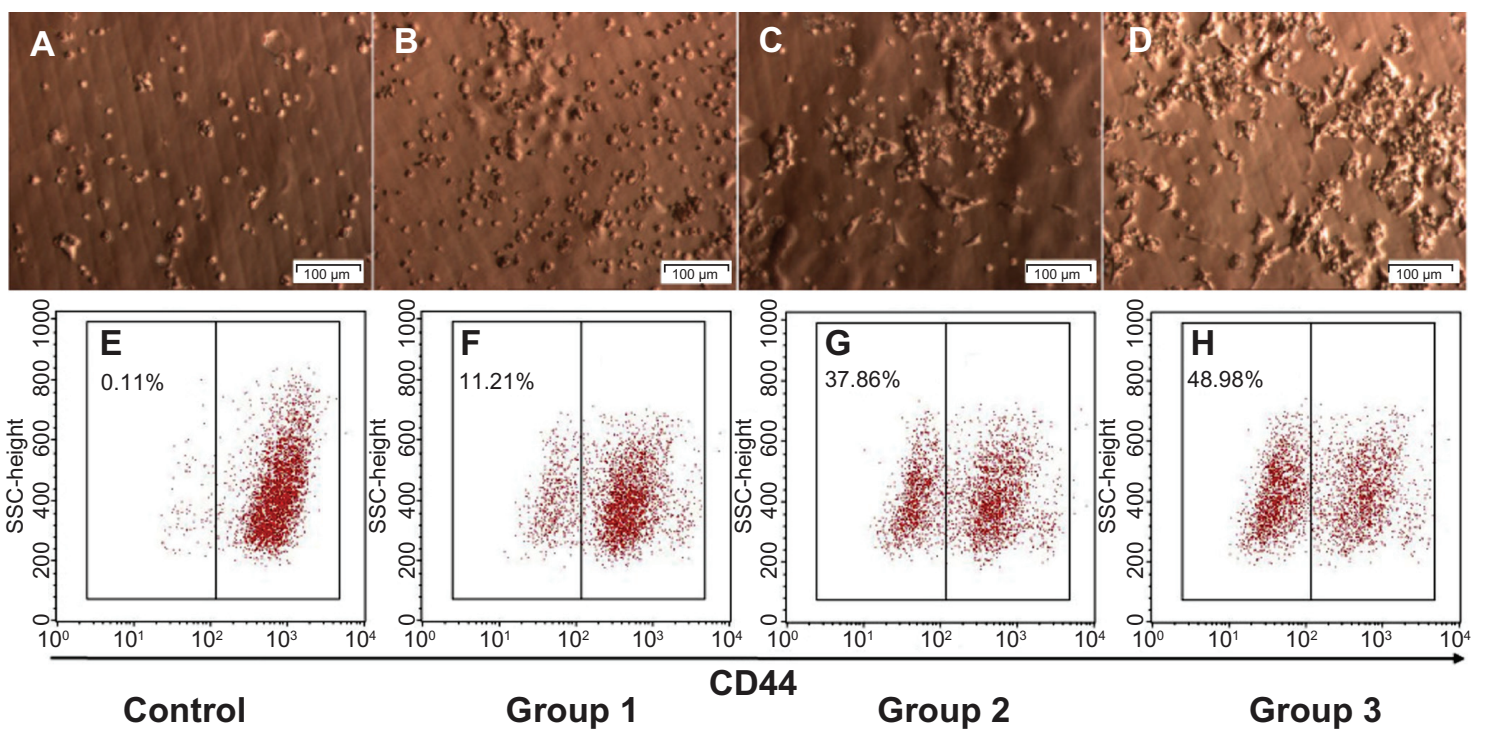

Figure 3 In vitro CD44 down-regulation using the CD44 shRNA lentiviral vector with doses of infectious units to breast cancer stem cells at ratios I:0 (A and E), 2:I (B and F), I:I (C and $\mathbf{G}$ ) and I:2 (D and $\mathbf{H})$. 
A

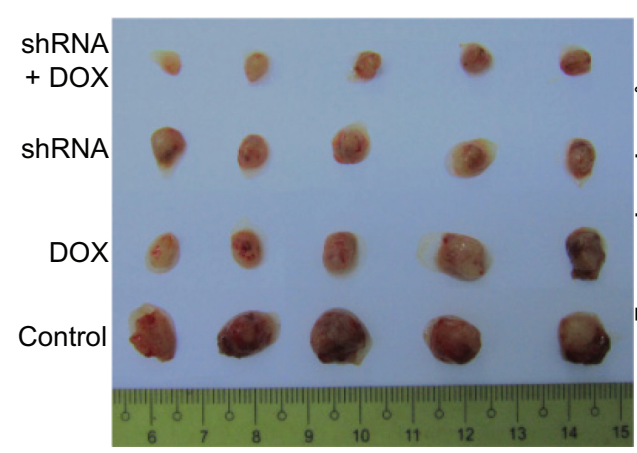

B

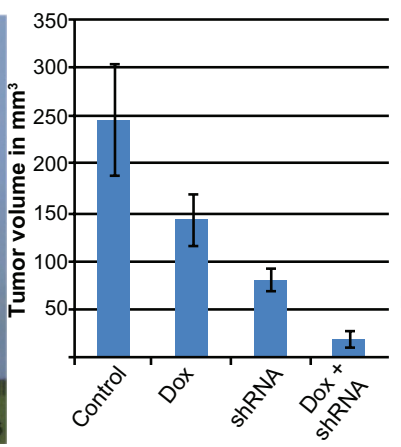

C

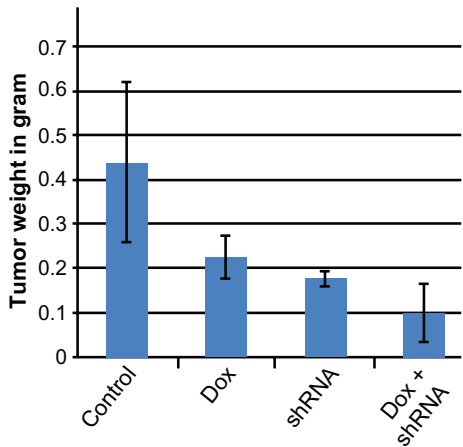

Figure 4 Tumor size and weight in experimental groups (A). Graphs of the differences in the size (B) and weight (C) of tumors in control, Dox, CD44 shRNA, and CD44 shRNA + Dox groups.

Abbreviation: Dox, doxorubicin.

confirmed in solid tumors of the brain, prostate, pancreas, liver, colon, head and neck, lung, and skin. ${ }^{36-42}$ Moreover, $\mathrm{CD} 44^{+} \mathrm{CD} 24^{-}$cells have been identified as breast cancer stem cells. $^{21}$

Since the discovery of cancer stem cells, the study of cancer treatment in general, and breast cancer in particular, has gradually focused on targeting cancer stem cells. Thus far, targeting of breast cancer stem cells has been performed using various approaches, but has mainly targeted selfrenewal and differentiation of breast cancer stem cells. To influence self-renewal and differentiation, signaling pathways that are important in breast cancer stem cells, such as Wnt, Notch, and Hedgehog, can be targeted. ${ }^{43-46}$ There are numerous methods to target signaling pathways, including gene therapy, immunotherapy, and targeting the cell environment. In our previous study, we found that CD44 down-regulation reduces the drug resistance of breast cancer stem cells to Dox. ${ }^{30}$ In previous research, we also confirmed that CD44 shRNA lentiviral particles reduced CD44 expression and caused breast cancer stem cell differentiation. ${ }^{31}$ In this study, we used an experimental treatment to target breast cancer stem cells by combining gene therapy targeting CD44 and Dox treatment.

First, we established a breast cancer stem cell line that stably expressed GFP to monitor the xenografted breast cancer tumor in mice. To establish this cell line, breast cancer stem cells were transduced with a lentiviral vector carrying $g f p$ and a puromycin resistance gene for selection. Because random insertion of lentiviral DNA into the genome can cause detrimental mutations, we isolated $\mathrm{CD} 44^{+} \mathrm{CD} 24^{-}$cells from GFP-breast cancer stem cells using a magnetic cell separation method, and re-analyzed with flow cytometry. Indeed, a study showed that lentiviral vectors demonstrate a low tendency to integrate into genes that cause cancer, ${ }^{47}$ and another study found no increase in tumor incidence and no earlier onset of tumors in a mouse strain following the use of lentiviral vectors. ${ }^{48}$

These BSCS1 cells were used to evaluate the potential to form tumors in NOD/SCID mice and CD44 knockdown mice using a CD44 shRNA lentiviral vector as well as determination of the optimal dose of lentiviral particles for in vivo analyses. GFP-expressing BCSC1 maintained a tumorigenic capacity and formed malignant tumors in NOD/SCID mice with numerous poorly differentiated and abnormal cells.

Next, we determined the appropriate dose of virus particles to infect tumors, which was considered to be the IFUs that down-regulated CD44 at the highest rate. To determine the appropriate dose, we conducted serial assays with ratios between cells and IFUs at 2:1, 1:1, and 1:2. CD44 downregulation was highest using double the IFUs compared with that of the cell number. To determine the number of cells in a tumor, we measured the tumor size at the time of treatment. The number of tumor cells is calculated as $1 \mathrm{~cm}^{3}$ tumor contains $\sim 1 \times 10^{9}$ cells. ${ }^{49}$ Although recent studies have supported this claim, ${ }^{50-52}$ experiments using the same mouse breed under the same conditions are necessary to apply this rule in calculation and comparison among the mice.

Lentiviral vector-injected mice were treated with Dox after 48 hours. This period was chosen because previous study has shown that viruses infect target cells and inhibit CD44 expression after 24 hours. ${ }^{30}$ The Dox dose used was $2 \mathrm{mg} / \mathrm{kg}$ body weight and this was chosen based on a previous study. ${ }^{53}$

The results showed significant differences in the size and weight of tumors of treated mice compared with those of the controls. Dox treatment and CD44 siRNA therapy alone or in combination inhibited tumor growth. Tumor inhibition with Dox treatment and CD44 shRNA therapy alone was identical, 
while a significant difference $(P<0.05)$ was demonstrated between combinatorial therapy with Dox and CD44 shRNA compared with that of single treatments.

CD44 down-regulation also effects adhesion, invasion, and metastasis, ${ }^{54-59}$ and the inhibition of CD44 is also considered as treatment therapy in many cancer targets. ${ }^{57-59}$ In addition, CD44 down-regulation that suppresses the development of tumors has also been shown in in vivo colon cancer tumors, ${ }^{33}$ ovarian cancer cells,${ }^{34}$ and nasopharyngeal carcinoma cells. ${ }^{60-61}$ In recent research, we recognized that CD44 maintains the stemness of breast cancer stem cells. CD44 knocked-down breast cancer stem cells by CD44 shRNA lentiviral particles can cause differentiation of breast cancer stem cells or loss of stemness can change the tumor formation and metastasis related genes, and can reduce tumor formations in NOD/SCID mice. ${ }^{31}$

CD44 down-regulation using shRNA suppressed xenografted breast tumor growth in a mouse model with or without Dox treatment. However, there are limitations for the clinical application of this therapy. The two most significant issues are the host's immune response to the lentiviral vector and random insertion mutagenesis. The immune response to the lentiviral vector is very low because viral proteins are not translated. Therefore, an immune response occurs only as a primary response to the virus or products of transgenes. In this study, the lentiviral vector was only transcribed into shRNA. Moreover, an immune response occurs only in response to adenoviral vectors or in the nature of the mechanism of adeno-associated viral production of antibodies against them, ${ }^{62}$ while lentiviral vectors possess many traits that enable avoidance of the immune response. As mentioned, insertion mutations caused by lentiviral vectors are fewer and less serious compared with those caused by other vectors. Insertion mutations have been detected in three out of eleven cross-linked SCID children after applying ex vivo therapy using a murine leukemia virus vector. ${ }^{63}$ Murine leukemia virus vectors are often inserted into promoters and $\mathrm{CpG}$ islands that affect transcriptionally active genes. ${ }^{64,65}$ Integrations near transcription start sites may increase oncogenesis, either by influencing the activity of host promoters or producing new full-length transcripts. In contrast, lentiviral vectors that integrate into the entire transcribed region are less likely to disturb the regulation and expression of host genes. ${ }^{66}$ This claim is supported by a Montini et al, ${ }^{48}$ which showed that lentiviral vectors cause insertion mutations related to cancer less often compared with murine leukemia virus vectors in a mouse model. However, these problems can be solved by using site-specific gene transfer. With the structural advantages of this vector system, cassettes that contain numerous genes can be expressed in the same vector, such as a Cre recombinase in combination with $\operatorname{lox} P$ sites or a zinc finger nuclease. However, there are some limitations in applying these results in clinical trials. First, the high dose of lentiviral vector can cause some side effects; in particular, lentiviral vectors can migrate into bone marrow to suppress the mesenchymal stem cells and other cells that strongly express CD44. Second, in practice, intratumoral delivery is not generally carried out. However, as many kinds of cells as well as stem cells strongly express CD44, we cannot apply systemic therapy in this case.

\section{Conclusion}

Strong CD44 expression in a breast cancer stem cell population with a $\mathrm{CD} 44^{+} \mathrm{CD} 24^{-}$phenotype plays a pivotal role in the proliferation and drug resistance of malignant cells. Our data suggest that CD44 down-regulation suppresses tumor growth in a mouse model. Combinatorial therapy of CD44 down-regulation using a CD44 shRNA lentiviral vector and Dox treatment strongly inhibits tumor growth. These results support a new targeted therapy using gene therapy and chemotherapy to eradicate breast cancer stem cells. If this therapy is found to be safe, it may be a promising therapy for breast cancer through the targeting of breast cancer stem cells.

\section{Disclosure}

The authors report no conflicts of interest in this work.

\section{References}

1. Meyer MJ, Fleming JM, Ali MA, Pesesky MW, Ginsburg E, Vonderhaar BK. Dynamic regulation of $\mathrm{CD} 24$ and the invasive, CD44posCD24neg phenotype in breast cancer cell lines. Breast Cancer Res. 2009; 11:R82.

2. Sheridan C, Kishimoto H, Fuchs RK, et al. $\mathrm{CD} 44^{+} / \mathrm{CD} 24^{-}$breast cancer cells exhibit enhanced invasive properties: an early step necessary for metastasis. Breast Cancer Res. 2006;8:R59.

3. Tiezzi DG, Valejo FA, Marana HR, et al. CD44(+)/CD24(-) cells and lymph node metastasis in stage I and II invasive ductal carcinoma of the breast. Med Oncol. Epub June 29, 2011.

4. Johnston SR. Targeting downstream effectors of epidermal growth factor receptor/HER 2 in breast cancer with either farnesyltransferase inhibitors or mTOR antagonists. Int J Gynecol Cancer. 2006;16:543-548.

5. Nanda R. Targeting the human epidermal growth factor receptor 2 (HER2) in the treatment of breast cancer: recent advances and future directions. Rev Recent Clin Trials. 2007;2:111-116.

6. Piechocki MP, Yoo GH, Dibbley SK, Lonardo F. Breast cancer expressing the activated HER2/neu is sensitive to gefitinib in vitro and in vivo and acquires resistance through a novel point mutation in the HER2/neu. Cancer Res. 2007;67:6825-6843.

7. Reid A, Vidal L, Shaw H, de Bono J. Dual inhibition of ErbB1 (EGFR/ HER1) and ErbB2 (HER2/neu). Eur J Cancer. 2007;43:481-489. 
8. Santin AD, Bellone S, Roman JJ, McKenney JK, Pecorelli S. Trastuzumab treatment in patients with advanced or recurrent endometrial carcinoma overexpressing HER2/neu. Int $J$ Gynaecol Obstet. 2008;102:128-131.

9. Freudenberg JA, Wang Q, Katsumata M, Drebin J, Nagatomo I, Greene MI. The role of HER2 in early breast cancer metastasis and the origins of resistance to HER2-targeted therapies. Exp Mol Pathol. 2009;87: 1-11.

10. Diermeier-Daucher S, Breindl S, Buchholz S, Ortmann O, Brockhoff G. Modular anti-EGFR and anti-Her2 targeting of SK-BR-3 and BT474 breast cancer cell lines in the presence of ErbB receptor-specific growth factors. Cytometry A. 2011;79A:684-693.

11. Liu T, Yacoub R, Taliaferro-Smith LD, et al. Combinatorial effects of lapatinib and rapamycin in triple-negative breast cancer cells. Mol Cancer Ther. 2011;10:1460-1469.

12. Massarweh S, Osborne CK, Creighton CJ, et al. Tamoxifen resistance in breast tumors is driven by growth factor receptor signaling with repression of classic estrogen receptor genomic function. Cancer Res. 2008;68:826-833.

13. Yonesaka K, Zejnullahu K, Okamoto I, et al. Activation of ERBB2 signaling causes resistance to the EGFR-directed therapeutic antibody cetuximab. Sci Transl Med. 2011;3:99ra86-99ra86.

14. Chen YJ, Huang WC, Wei YL, et al. Elevated BCRP/ABCG2 expression confers acquired resistance to gefitinib in wild-type EGFR-expressing cells. PLoS One. 2011;6:e21428.

15. Jin K, Kong X, Shah T, Penet MF, et al. The HOXB7 protein renders breast cancer cells resistant to tamoxifen through activation of the EGFR pathway. Proc Natl Acad Sci U SA. Epub June 20, 2011.

16. Brand TM, Iida M, Wheeler DL. Molecular mechanisms of resistance to the EGFR monoclonal antibody cetuximab. Cancer Biol Ther. 2011;11 777-792.

17. Idowu MO, Kmieciak M, Dumur C, et al. CD44(+)/CD24(-/low) cancer stem/progenitor cells are more abundant in triple-negative invasive breast carcinoma phenotype and are associated with poor outcome. Hum Pathol. Epub August 10, 2011.

18. Bates RC, Edwards NS, Burns GF, Fisher DE. A CD44 survival pathway triggers chemoresistance via lyn kinase and phosphoinositide 3-kinase/ Akt in colon carcinoma cells. Cancer Res. 2001;61:5275-5283.

19. Shen $\mathrm{S}$, Yang W, Wang Z, et al. Tumor-initiating cells are enriched in CD44 population in murine salivary gland tumor. PLoS One. 2011;6: e23282.

20. Ouhtit A, Abd Elmageed ZY, Abdraboh ME, Lioe TF, Raj MH. In vivo evidence for the role of CD44s in promoting breast cancer metastasis to the liver. Am J Pathol. 2007;171:2033-2039.

21. Al-Hajj M, Wicha MS, Benito-Hernandez A, Morrison SJ, Clarke MF. Prospective identification of tumorigenic breast cancer cells. Proc Natl Acad Sci U S A. 2003;100:3983-3988.

22. Faber A, Barth C, Hörmann K, et al. CD44 as a stem cell marker in head and neck squamous cell carcinoma. Oncol Rep. 2011;26:321-632.

23. Chikamatsu K, Ishii H, Takahashi G, et al. Resistance to apoptosisinducing stimuli in CD44+ head and neck squamous cell carcinoma cells. Head Neck. Epub April 5, 2011.

24. Kokko LL, Hurme S, Maula SM, et al. Significance of site-specific prognosis of cancer stem cell marker CD44 in head and neck squamouscell carcinoma. Oral Oncol. 2011;47:510-516.

25. Zhao JS, Li WJ, Ge D, et al. Tumor initiating cells in esophageal squamous cell carcinomas express high levels of CD44. PLoS One. 2011;6:e21419.

26. Su J, Xu XH, Huang Q, et al. Identification of cancer stem-like CD44+ cells in human nasopharyngeal carcinoma cell line. Arch Med Res. 2011; 42:15-21.

27. Zhang C, Li C, He F, Cai Y, Yang H. Identification of CD44+CD24+ gastric cancer stem cells. J Cancer Res Clin Oncol. Epub September 1, 2011.

28. Chen KL, Pan F, Jiang H, et al. Highly enriched CD133(+)CD44(+) stem-like cells with CD133(+)CD44 (high) metastatic subset in HCT116 colon cancer cells. Clin Exp Metastasis. Epub July 13, 2011.
29. Fang XJ, Jiang H, Zhao XP, Jiang WM. The role of a new CD44st in increasing the invasion capability of the human breast cancer cell line MCF-7. BMC Cancer. 2011;11:290.

30. Phuc PV, Nhan PL, Nhung TH, et al. Downregulation of CD44 reduces doxorubicin resistance of CD44CD24 breast cancer cells. Onco Targets Ther. 2011;4:71-78.

31. Pham PV, Phan NL, Nguyen NT, et al. Differentiation of breast cancer stem cells by knockdown of CD44: promising differentiation therapy. J Transl Med. 2011;9:209.

32. Abdraboh ME, Gaur RL, Hollenbach AD, Sandquist D, Raj MH, OuhtitA. Survivin is a novel target of CD44-promoted breast tumor invasion. Am J Pathol. 2011;179:555-563.

33. Subramaniam V, Vincent IR, Gilakjan M, Jothy S. Suppression of human colon cancer tumors in nude mice by siRNA CD44 gene therapy. Exp Mol Pathol. 2007;83:332-340.

34. Li CZ, Liu B, Wen ZQ, Li HY. Inhibition of CD44 expression by small interfering RNA to suppress the growth and metastasis of ovarian cancer cells in vitro and in vivo. Folia Biol (Praha). 2008;54:180-186.

35. Huang X, Sheng Y, Guan M. Co-expression of stem cell genes CD133 and CD44 in colorectal cancers with early liver metastasis. Surg Oncol. Epub July 14, 2011

36. Rak J, Mitsuhashi Y, Bayko L, et al. Mutant ras oncogenes upregulate VEGF/VPF expression: implications for induction and inhibition of tumor angiogenesis. Cancer Res. 1995;55:4575-4580.

37. Antón Aparicio LM, Cassinello Espinosa J, García Campelo R, Gómez Veiga F, Díaz Prado S, Aparicio Gallego G. Prostate carcinoma and stem cells. Clin Transl Oncol. 2007;9:66-76.

38. Eramo A, Lotti F, Sette G, et al. Identification and expansion of the tumorigenic lung cancer stem cell population. Cell Death Differ. 2008;15: 504-514.

39. Glinsky GV. Stem cell origin of death-from-cancer phenotypes of human prostate and breast cancers. Stem Cell Rev. 2007;3:79-93.

40. Li C, Heidt DG, Dalerba P, et al. Identification of pancreatic cancer stem cells. Cancer Res. 2007;67:1030-1037, 2007.

41. Prince ME, Sivanandan R, Kaczorowski A, et al. Identification of a subpopulation of cells with cancer stem cell properties in head and neck squamous cell carcinoma. Proc Natl Acad Sci U SA. 2007;104: 973-978.

42. Seo DC, Sung JM, Cho HJ, et al. Gene expression profiling of cancer stem cell in human lung adenocarcinoma A549 cells. Mol Cancer. 2007;6:75.

43. Vorechovsky' I, Benediktsson KP, Toftgård R. The patched/hedgehog/ smoothened signalling pathway in human breast cancer: no evidence for H133Y SHH, PTCH, and SMO mutations. Eur J Cancer. 1999;35:711-713.

44. Soriano JV, Uyttendaele H, Kitajewski J, Montesano R. Expression of an activated Notch4(int-3) oncoprotein disrupts morphogenesis and induces an invasive phenotype in mammary epithelial cells in vitro. Int J Cancer. 2000;86:652-659.

45. Kelly OG, Pinson KI, Skarnes WC. The Wnt co-receptors Lrp5 and Lrp6 are essential for gastrulation in mice. Development. 2004;131: 2803-2815.

46. Huelsken J, Vogel R, Brinkmann V, Erdmann B, Birchmeier C, Birchmeier W. Requirement for beta-catenin in anterior-posterior axis formation in mice. $J$ Cell Biol. 2000;148:567-578.

47. Cattoglio C, Facchini G, Sartori D, et al. Hot spots of retroviral integration in human CD34+ hematopoietic cells. Blood. 2007;110:1770-1778.

48. Montini E, Cesana D, Schmidt M, et al. Hematopoietic stem cell gene transfer in a tumor-prone mouse model uncovers low genotoxicity of lentiviral vector integration. Nat Biotechnol. 2006;24:687-696.

49. DeVita VT Jr, Young RC, Canellos GP. Combination versus single agent chemotherapy: a review of the basis for selection of drug treatment of cancer. Cancer. 1975;35:98-110.

50. Evans PM. Anatomical imaging for radiotherapy. Phys Med Biol. 2008;53:R151-R191.

51. Olivotto M, Dello Sbarba P. Environmental restrictions within tumor ecosystems select for a convergent, hypoxia-resistant phenotype of cancer stem cells. Cell Cycle. 2008;7:176-187. 
52. Blagosklonny MV. Research by retrieving experiments. Cell Cycle. 2007;6:1277-1283.

53. Ottewell PD, Mönkkönen H, Jones M, Lefley DV, Coleman RE, Holen I. Antitumor effects of doxorubicin followed by zoledronic acid in a mouse model of breast cancer. J Natl Cancer Inst. 2008;100:1167-1178.

54. Xie Z, Choong PF, Poon LF, et al. Inhibition of CD44 expression in hepatocellular carcinoma cells enhances apoptosis, chemosensitivity, and reduces tumorigenesis and invasion. Cancer Chemother Pharmacol. 2008;62:949-957.

55. Henry JC, Park JK, Jiang J, et al. miR-199a-3p targets CD44 and reduces proliferation of CD44 positive hepatocellular carcinoma cell lines. Biochem Biophys Res Commun. 2010;403:120-125.

56. Yang K, Tang Y, Habermehl GK, Iczkowski KA. Stable alterations of CD44 isoform expression in prostate cancer cells decrease invasion and growth and alter ligand binding and chemosensitivity. BMC Cancer. 2010;10:16.

57. Krause DS, Lazarides K, von Andrian UH, Van Etten RA. Requirement for CD44 in homing and engraftment of BCR-ABL-expressing leukemic stem cells. Nat Med. 2006;12:1175-1180.

58. Ponta H, Sherman L, Herrlich PA. CD44: from adhesion molecules to signaling regulators. Nat Rev Mol Cell Biol. 2003;4:33-45.

59. Shipitsin M, Campbell LL, Argani P, et al. Molecular definition of breast tumor heterogeneity. Cancer Cell. 2007;11:259-273.
60. Shi Y, Tian Y, Zhou YQ, et al. Inhibition of malignant activities of nasopharyngeal carcinoma cells with high expression of CD44 by siRNA. Oncol Rep. 2007;18:397-403.

61. Jod JY, Shi Y, Zhou YQ, et al. Experimental siCD44-targeted therapy of human nasopharyngeal carcinoma mediated by adenovirus. Zhongguo Yi Xue Ke Xue Yuan Xue Bao. 2007;29:626-630. Chinese.

62. Bessis N, GarciaCozar FJ, Boissier MC. Immune responses to gene therapy vectors: influence on vector function and effector mechanisms. Gene Ther. 2004;11:S10-S17.

63. Hacein-Bey-Abina S, Von Kalle C, Schmidt M, et al. LMO2-associated clonal $\mathrm{T}$ cell proliferation in two patients after gene therapy for SCID-X1. Science. 2003;302:415-419.

64. Schroder AR, Shinn P, Chen H, Berry C, Ecker JR, Bushman F. HIV-1 integration in the human genome favors active genes and local hotspots. Cell. 2002;110:521-529.

65. Mitchell RS, Beitzel BF, Schroder AR, et al. Retroviral DNA integration: ASLV, HIV, and MLV show distinct target site preferences. PLoS Biol. 2004;2:E234.

66. Jakobsson J, Lundberg C. Lentiviral vectors for use in the central nervous system. Mol Ther. 2006;13:484-493.
OncoTargets and Therapy

\section{Publish your work in this journal}

OncoTargets and Therapy is an international, peer-reviewed, open access journal focusing on the pathological basis of all cancers, potential targets for therapy and treatment protocols employed to improve the management of cancer patients. The journal also focuses on the impact of management programs and new therapeutic agents and protocols on

\section{Dovepress}

patient perspectives such as quality of life, adherence and satisfaction The manuscript management system is completely online and includes a very quick and fair peer-review system, which is all easy to use. Visit http://www.dovepress.com/testimonials.php to read real quotes from published authors. 